\title{
Correction to: CRISPR-Cas9-mediated Gene Editing in Human Induced Pluripotent Stem Cells
}

\section{Stijn L. M. in 't Groen, Mike Broeders, and W. W. M. Pim Pijnappel}

\section{Correction to:}

Chapter 16 in: M. Tofazzal Islam and Kutubuddin Ali Molla (eds.), CRISPR-Cas Methods: Methods and Protocols, Springer Protocols Handbooks, vol. 8623, https://doi.org/10.1007/978-1-0716-1657-4_16

Chapter 16 was published non-open access. It has now been changed to open access under a CC BY 4.0 license and the copyright holder has been updated to "The Author(s)." This book has also been updated with these changes.

The updated version for this chapter can be found at https://doi.org/10.1007/978-1-0716-1657-4_16 